\title{
Factors Associated with Travel Time and Survival of Migrant Yearling Chinook Salmon and Steelhead in the Lower Snake River
}

\author{
Steven G. Smith,* William D. Muir, and John G. Williams \\ National Marine Fisheries Service, Northwest Fisheries Science Center, Fish Ecology Division, \\ 2725 Montlake Boulevard East, Seattle, Washington 98112, USA \\ JOHN R. SKALSKI \\ School of Aquatic and Fishery Sciences, University of Washington, 1325 Fourth Avenue, Suite \\ 1820, Seattle, Washington 98101-2509, USA
}

\begin{abstract}
Simple and multiple linear regressions were used to evaluate factors associated with travel time and survival of yearling chinook salmon Oncorhynchus tshawytscha and steelhead $O$. mykiss migrating in the lower Snake River. Factors were release date and environmental variables measuring river discharge (flow), water temperature, and the percentage of total flow passed over spillways at dams. Data were collected from migrant salmonids tagged with passive integrated transponder (PIT) tags from 1995 through 1999. The greatest distance over which survival could be estimated during all 5 years was from the Lower Granite Dam tailrace to the McNary Dam tailrace (225 river km encompassing four dams and reservoirs). Release groups consisted of PITtagged fish leaving Lower Granite Dam daily. Data from more than 451,000 PIT-tagged yearling chinook salmon and 204,000 PIT-tagged steelhead were analyzed. For each daily group, indices of exposure to environmental factors were calculated as the average value for the factor during an index period of the group's downstream passage. For both species, flow volume and travel time were strongly correlated within single years, and the regression equation was consistent from year to year. Survival estimates changed very little within any given migration season, despite sometimes great fluctuations in environmental factors. Correlations between river discharge and survival between Lower Granite Dam and McNary Dam and between travel time and survival were neither strong (within or between years) nor consistent from year to year. Thus, survival benefits to the stocks from increased flow in this stretch of the river were at best minimal; any measurable benefits occurred downstream from the Snake River.
\end{abstract}

The effects of dams and river discharge (flow) on travel time and survival of juvenile salmonids (smolts) migrating seaward have been much debatedin the Pacific Northwest (Cada et al. 1995; Williams et al. 1996). Smolt migration rates increase as flow increases, presumably reducing their exposure to predators and disease in reservoirs behind hydroelectric dams. Moreover, faster migrations better approximate predam travel rates (Raymond 1979, 1988; Berggren and Filardo 1993). A presumed flow rate-survival relation is a cornerstone of the Fish and Wildlife Program of the Northwest Power Planning Council (Northwest Power Planning Council 1994). Setting flow targets for the juvenile salmonid migration is controversial, however, because meeting such targets may require release of stored water that was intended for irrigation or to generate power during low-flow months.

\footnotetext{
* Corresponding author: steven.g.smith@noaa.gov
}

Received October 28, 1999; accepted August 30, 2001
Correlation between flow and migration rate has been documented for many, but not all, stocks of juvenile salmonids migrating downstream in the Snake and Columbia rivers (Raymond 1979; Berggren and Filardo 1993; Giorgi et al. 1997; Zabel et al. 1998). However, the relation between flow and survival has been more difficult to investigate (National Research Council 1996; Williams et al. 1996). Historically, studies of travel time and environmental conditions were conducted with batch releases of nitrogen-freeze-branded juvenile salmonids (Raymond 1979; Berggren and Filardo 1993). Batch-branded groups allowed estimation of median travel time for the group but not reliable estimation of survival.

Development of the passive integrated transponder (PIT) tag for use in juvenile salmonids and installation of PIT tag detection systems at dams on the Snake and Columbia rivers (Prentice et al. 1990a, 1990b, 1990c) have provided more informative data for exploring relations among these variables, primarily because individual PITtagged fish can be tracked (Giorgi et al. 1997). 


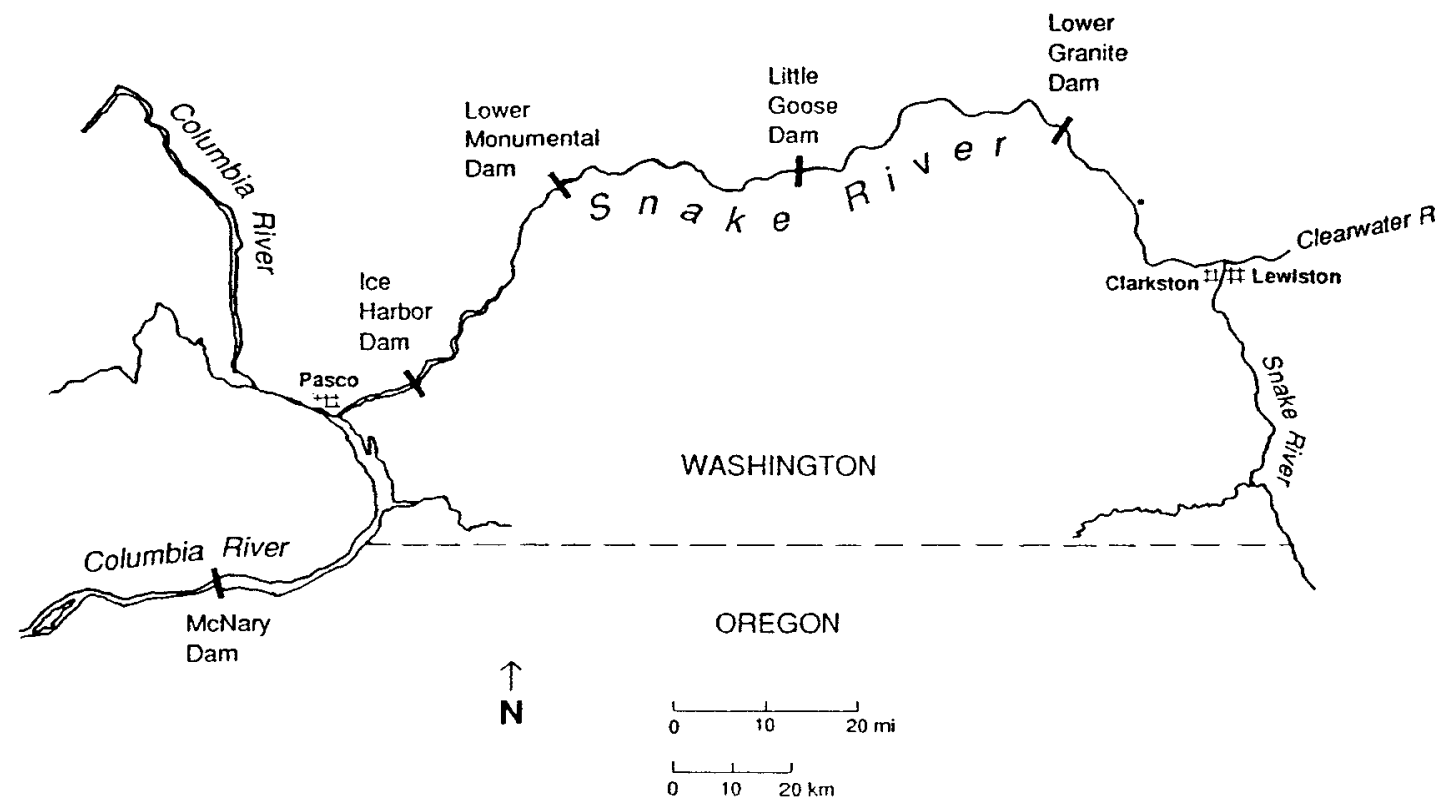

FIGURE 1.-Map of the study area.

When PIT-tagged fish are detected at multiple dams during their out-migration, their survival can be estimated by using standard tag-recapture models - although Giorgi et al. (1997) were unable to estimate survival because the subject fish did not pass enough dams equipped with detectors.

Since 1993, the National Marine Fisheries Service has used PIT-tagged migrant juvenile salmonids to estimate survival in the lower Snake River (Muir et al. 2001a). Beginning in 1995, the detection system was sufficiently developed in the Snake and Columbia rivers to allow estimation of survival of smolts as they migrated from points of release in the Snake River basin to McNary Dam, the first dam they encountered on the lower Columbia River. The objective of this paper is to assess relations among estimated survival as reported by Muir et al. (2001a), travel time, and selected environmental variables in the lower Snake River from 1995 through 1999.

\section{Methods}

Study area.-Data for the analyses were from yearling chinook salmon Oncorhynchus tshawytscha and steelhead $O$. mykiss that migrated from the Snake River basin, were guided into the juvenile collection system at Lower Granite Dam, and continued their migration below Lower Granite Dam through three more main-stem dams on the lower Snake River to McNary Dam on the lower Columbia River (Figure 1).
Release groups.-For each species, we analyzed groups of PIT-tagged fish released daily into the tailrace at Lower Granite Dam during the migration seasons of 1995 through 1999. Daily groups consisted of individuals that were collected and tagged in the juvenile salmonid collection facility at Lower Granite Dam and then released into the tailrace, and individuals that were tagged above Lower Granite Dam in hatcheries, spawning streams, or the main stem, and subsequently detected at the dam and returned to the river. Hatchery and wild fish were combined. Thus, each daily group consisted of actively migrating fish, all of which were known to be alive below Lower Granite Dam within the same 24-h period.

For some groups, data were insufficient to estimate survival to McNary Dam, and the group was combined with those from following days until a survival estimate was possible from the pooled data (Muir et al. 2001a). Thus, the "daily" group in those cases consisted of fish actually leaving Lower Granite Dam on two or more consecutive days.

Survival estimates.-Below Lower Granite Dam, PIT-tagged fish can be detected as they pass Little Goose Dam, Lower Monumental Dam, and McNary Dam. They can also be detected as they pass John Day Dam and Bonneville Dam on the lower Columbia River and finally by a net-mounted detector deployed from a trawler in the estuary. Because each PIT tag is uniquely coded, and be- 
cause most PIT-tagged fish were returned to the river to continue their migration after detection at the dams, the records of detections of individual tagged fish from a daily group constituted data suitable for survival estimation in a multiple-recapture model for single-release groups (Cormack 1964; Jolly 1965; Seber 1965).

The expression for the estimated variance for estimated survival is a function of various statistics summarizing detection histories multiplied by the term $\hat{S}^{2}$ (cf. Burnham et al. 1987:115). That is, estimated variance is a function of the estimate itself. In the ranges of survival and detection probability estimates observed in this study, the result of this functional relationship is a positive correlation between survival estimates and corresponding variance estimates. Accordingly, to correct for nonconstant variance in analyses of survival associations, we used weighted regression with weights equal to the inverse of the corresponding estimated relative variance. If inverse estimated absolute variance were used in weighting, lower survival estimates would tend to have disproportionate influence, and the resulting regression line would be biased toward the lower survival estimates.

Survival estimates are random variables, subject to sampling variability. Because of the model formulation, estimates of survival probabilities greater than 1.0 are possible, particularly when true survival probabilities are close to 1.0 or sampling variability is high (e.g., when release size is small). Estimates greater than 1.0 were included in regression analyses, but their corresponding variance estimates were always very large and had relatively little influence on the weighted regression results.

From 1995 through 1999, survival (SURV) from Lower Granite Dam tailrace to McNary Dam tailrace was estimated for as many daily groups as possible (Muir et al. 2001a). The annual series of daily groups began on the earliest day of the year for which a survival estimate to McNary Dam was possible and continued to 31 May. Beginning dates ranged from 2 April to 9 April for yearling chinook salmon and from 6 April to 11 April for steelheads. The 31 May ending date captured the bulk of the migration seasons while ensuring that the periods were comparable across years.

Travel time.-For each fish detected at McNary Dam, we calculated travel time (d) from Lower Granite Dam tailrace to McNary Dam. Regardless of precise release or passage times at Lower Granite Dam, we used a standardized release time of 1200 hours for travel time calculation for all fish in a particular daily group. Thus, we used the same release time for all fish in a pooled group. Travel time included the time required to move through four reservoirs and four dams (Little Goose, Lower Monumental, Ice Harbor, and McNary) plus any delays associated with residence in forebays before passing through the dams.

For each daily group, we calculated the median travel time (TTIME) from Lower Granite Dam to McNary Dam among all fish in the group that were detected at McNary Dam. We also calculated a variable to represent the variability of travel times $(\Delta \mathrm{TT})$ within the group. The $\Delta \mathrm{TT}$ variable was computed as the difference in days between the 20th and 80th percentiles of travel times for the group. In some analyses we used TTIME and $\Delta \mathrm{TT}$ as dependent variables; in others, TTIME and $\Delta \mathrm{TT}$ were predictor variables.

Environmental conditions.-We considered the following environmental factors that potentially affect survival and travel time: river discharge $\left(1,000 \mathrm{~m}^{3} / \mathrm{s}\right)$, percentage of discharge that passed over spillways, and water temperature $\left({ }^{\circ} \mathrm{C}\right)$. Our objective was to devise an index that summarized exposure for a group of individual fish that passed four dams and $225 \mathrm{~km}$ of impounded water, typically over the course of 1-4 weeks. Measurements of flow, temperature, and spill volume were collected at dams, so we used index periods corresponding to the group's passage through a dam. Ice Harbor Dam was eliminated as an index site because no passage information was collected there. McNary Dam was eliminated because conditions there are strongly influenced by water from the upper Columbia River, which does not affect Snake River migrants when they are above the confluence (173 km of the migration distance). Measurements of discharge at Lower Granite, Little Goose, and Lower Monumental dams were highly correlated $\left(r^{2}=94.8-99.7 \%\right)$, as were measurements of water temperature $\left(r^{2}=65.4\right.$ $95.8 \%$ ). Survival and travel time measures for the groups began in the tailrace of Lower Granite Dam and probably were not influenced by spill at that dam. Spill percentage was highly correlated between Little Goose and Lower Monumental dams $\left(r^{2}=73.3-89.2 \%\right)$. For these reasons, we conclude that exposures in the Snake River were reasonably represented by measurements at either Little Goose Dam or Lower Monumental Dam. We selected the data from Lower Monumental Dam because it is the closer of the two dams to halfway through the stretch in which we estimated survival and travel time. 
We obtained the mean daily value of each variable from pages on the World Wide Web, maintained by the Columbia Basin Research group of the University of Washington, School of Aquatic and Fishery Sciences (Data Access in Real Time [DART]; http://www.cbr.washington.edu/dart/dart. html) and by the Fish Passage Center (http:// www.fpc.org). These Web pages summarize data collected hourly over the last 20-30 years by the U.S. Army Corps of Engineers at each dam on the lower Snake and lower Columbia rivers.

For each daily group, we calculated an index of exposure to each environmental variable based on the group's distribution of PIT tag detections at Lower Monumental Dam. We first calculated the dates on which the 25th and 75th percentiles of the group's distribution of detections occurred. The index of exposure was calculated as the mean of the daily values of the variable during the period between the 25th and 75th percentiles of the detection distribution (FLOW, SP\%, and TEMP for flow, spill percentage, and temperature, respectively). We also calculated a variable ( $\triangle$ FLOW) to reflect the variability of flow during the time a group was passing. This variable was computed as the difference between the maximum and minimum flow during the period between the 25 th and 75 th percentiles of passage. Because temperature data on DART for Lower Monumental Dam in 1996 appeared corrupt, we used the temperature exposure index calculated for Little Goose Dam passage for groups in 1996.

The final variable considered was release date (DATE), expressed as the day of the year (e.g., 1 April $=91$ and 31 May $=151$ in a nonleap year). For release groups combined across days, DATE was calculated as the average release date (e.g., 1-2 April = 91.5). Associations of independent variables with release date may be related to differences in smolt development and physiological profiles of groups of fish passing Lower Granite Dam at different times during the migration season. The degree of smoltification (i.e., propensity to migrate) of fish passing Lower Granite Dam may increase through time, because water temperature increases and the fish have been in the river longer before arriving at Lower Granite Dam.

Associations among survival, travel time, and environmental variables.-For each year separately, we plotted dependent variables (SURV, TTIME, or $\Delta \mathrm{TT}$ ) against corresponding independent variables in an $x-y$ scatterplot and used linear regression (Sokal and Rohlf 1981) to describe the relation between the exposure and response. Sur- vival estimates greater than 1.5 were omitted from the scatterplots. Over the 5 years, survival estimates were greater than 1.5 for 9 groups (of 230) of yearling chinook salmon and 10 groups (of 207) of steelhead. In some instances, associations did not appear linear. In analyses of survival associations, we used weighted regression to correct for nonconstant variance, with weights equal to the inverse of the corresponding estimated relative variance (see above). For regression analyses of observed quantities TTIME and $\Delta \mathrm{TT}$, weights were equal for all points.

We compared relations from year to year by using analysis of covariance (ANCOVA) models. These models included variables for "year effects" to account for differences in annual mean survival that were not captured by the environmental variables. Using year-effect variables, we estimated a set of regression models and performed tests of hypotheses among them for each independent variable. We computed the following standard set of regression models for each independent variable (cf. Weisberg 1985):

Unique regressions: Intercept and slope both depend on year;

Parallel regressions: Intercept varies among years, slope identical in all years;

Common regression: Identical equation for all years;

Year effect: No regression relation (slope is 0 for all years), mean survival varies among years; and

No effect: No regression relation, mean survival is identical in all years.

Models with intercepts equal but slopes different across years, and models with intercepts equal to 0 , were not considered. The five models we did consider do not form a completely nested sequence. We identified a candidate model for a particular combination of species, independent variable, and dependent variable, beginning with the model with the most parameters (unique) then omitting nonsignificant $(\alpha=0.05)$ parameters in a stepwise procedure, using the following series of hypothesis tests:

(1) Parallel versus unique: If parallel was rejected (different slopes were required for each year), then we selected unique. If not rejected, we computed test 2.

(2) Year effect versus parallel: If year effect was rejected (common slope for all years was signifi- 
cantly different from zero), we computed test 3 . If not rejected, we computed test 4 .

(3) Common versus parallel: If common was rejected (intercepts, or baseline survival, were significantly different among years), we selected parallel. If not rejected, we selected common.

(4) No effect versus year effect: If no effect was rejected (annual mean survival was significantly different among years), we selected year effect. If not rejected, we selected no effect.

With the number of data points in the analyses, the tests were quite powerful, especially when within-year variability about the regression lines was relatively low. However, for several reasons, $P$-values for the tests were only approximate. For example, weights for the respective points in analyses of survival were estimated, not known. Also, error variance was unequal among years in several of the analyses. Parameter estimates (e.g., slope coefficients for environmental variables and intercepts for individual years) are robust to violation of the assumption of equal variance (Neter et al. 1985), but error estimates, and hence distributional results for test statistics, are biased. Consequently, we used the test sequence only as a guideline for identifying candidate models. In some cases, we used more subjective criteria in selecting the model that best represented the relationship. For example, the candidate model identified by the tests sometimes included parameters that were statistically significant, but the difference between the candidate model and a more restricted model was not biologically meaningful.

Finally, we explored multiple regression (ANCOVA) models that included year-effects variables and two or more quantitative environmental variables. Because the independent variables were correlated with each other, and because some relations had notable nonlinearity, we checked multiple regression models by using the generalized additive model ("gam") function of S-Plus (MathSoft, Inc. 2000). We used the nonparametric splines calculated in the gam function to suggest parametric curve functions (polynomials) to use in parametric multiple regression models. Resulting multiple regression models were rejected if graphic inspection of residuals revealed remaining nonlinearity or notable lack of normality. Partial fits of predictor variables from the generalized additive models were plotted without vertical axis labels because the transformed and scaled vertical axis in partial fit plots makes interpretation of units difficult. The relative influence of individual pre-
TABLE 1.-Year, date of release, number of release groups, and number of fish in release groups.

\begin{tabular}{|c|c|c|c|c|}
\hline Year & $\begin{array}{c}\text { Release } \\
\text { dates }\end{array}$ & $\begin{array}{c}\text { Number } \\
\text { of } \\
\text { groups }\end{array}$ & $\begin{array}{l}\text { Fish per } \\
\text { group }\end{array}$ & $\begin{array}{c}\text { Total } \\
\text { number } \\
\text { of fish }\end{array}$ \\
\hline \multicolumn{5}{|c|}{ Yearling chinook salmon } \\
\hline 1995 & 9 Apr-31 May & 44 & $430-9,355$ & 160,589 \\
\hline 1996 & 9 Apr-31 May & 38 & $505-5,556$ & 89,051 \\
\hline 1997 & 6 Apr-31 May & 29 & $29-374$ & 7,588 \\
\hline 1998 & 2 Apr-31 May & 58 & $39-5,749$ & 98,412 \\
\hline 1999 & 1 Apr-31 May & 61 & $12-6,234$ & 95,548 \\
\hline Total & & 230 & $29-9,355$ & 451,188 \\
\hline \multicolumn{5}{|c|}{ Steelhead } \\
\hline 1995 & 10 Apr-31 May & 24 & $26-2,649$ & 23,357 \\
\hline 1996 & 11 Apr-31 May & 26 & $18-3,768$ & 28,502 \\
\hline 1997 & 7 Apr-31 May & 43 & $12-1,695$ & 32,367 \\
\hline 1998 & 6 Apr-31 May & 55 & $32-2,330$ & 44,349 \\
\hline 1999 & 1 Apr-31 May & 59 & $8-4,077$ & 75,994 \\
\hline Total & & 207 & $12-3,768$ & 204,569 \\
\hline
\end{tabular}

dictor variables can be gauged by the relative range of the partial fit functions, and the shape of the nonlinear relation between predictor and dependent variable can be seen.

\section{Results}

\section{Yearling Chinook Salmon}

We analyzed 230 daily groups $(451,188$ fish) of PIT-tagged yearling chinook salmon (Table 1). Consistent temporal trends in the variables (i.e., correlations with DATE) were observed within the seasons of the study. As migration seasons progressed, FLOW, SP\%, and TEMP tended to increase, whereas TTIME and $\Delta \mathrm{TT}$ tended to decrease (Table 2). There was also a slight tendency for $\triangle \mathrm{FLOW}$ to decrease throughout the season. The temporal trends resulted in various degrees of correlation among the environmental variables. None was consistently, strongly correlated with SURV.

Differences in annual mean TTIME accounted for only $12.6 \%$ of the overall variability in median travel time ( $r^{2}$ for year-effect model). Correlations between TTIME and DATE and between TTIME and FLOW were relatively strong for most years (Table 2). Linear regression equations were consistent from year to year, but several of the years showed a consistent form of nonlinearity in the relations between TTIME and DATE and between TTIME and FLOW (Figures 2, 3). To the degree that release date acts as a surrogate for physiological status, the patterns suggest that the average degree of smoltification of fish passing Lower Granite Dam generally increases more rapidly early in the season than it does later. Unique regressions were selected 
TABLE 2.-Product-moment correlation coefficients $(r)$ among dependent and independent variables for daily release groups of yearling chinook salmon from Lower Granite Dam, 1995-1999. Results for survival probability estimates (SURV) are weighted by the inverse of relative variance. Variables are defined as follows: DATE $=$ release date, FLOW $=$ mean flow, $\mathrm{SP} \%=$ spill percentage, $\mathrm{TEMP}=$ temperature, $\Delta \mathrm{FLOW}=$ variability in flow, $\mathrm{TT}=$ median travel time, and $\Delta \mathrm{TT}=$ variability in travel time; $r^{2}>0.50 * *, 0.25<r^{2}<0.50 *$.

\begin{tabular}{|c|c|c|c|c|c|c|c|c|}
\hline \multirow[b]{2}{*}{ Year } & \multirow[b]{2}{*}{ Variable } & \multicolumn{7}{|c|}{ Variable } \\
\hline & & DATE & FLOW & $\mathrm{SP} \%$ & TEMP & $\Delta$ FLOW & TT & $\Delta \mathrm{TT}$ \\
\hline \multirow[t]{7}{*}{1995} & FLOW & $0.92^{* *} *$ & & & & & & \\
\hline & $\mathrm{SP} \%$ & 0.18 & 0.36 & & & & & \\
\hline & TEMP & $0.92 * *$ & $0.81 * *$ & 0.01 & & & & \\
\hline & $\Delta$ FLOW & -0.20 & -0.20 & 0.18 & -0.14 & & & \\
\hline & $\mathrm{TT}$ & $-0.75^{* *}$ & $-0.80 * *$ & -0.40 & -0.46 & 0.22 & & \\
\hline & $\Delta \mathrm{TT}$ & -0.25 & -0.31 & -0.32 & 0.03 & -0.01 & $0.68 *$ & \\
\hline & SURV & 0.05 & 0.03 & 0.19 & -0.22 & -0.06 & -0.24 & -0.27 \\
\hline \multirow[t]{7}{*}{1996} & FLOW & 0.38 & & & & & & \\
\hline & $\mathrm{SP} \%$ & $0.53^{*}$ & $0.79 * *$ & & & & & \\
\hline & TEMP & $0.77^{* *}$ & 0.36 & 0.41 & & & & \\
\hline & $\Delta$ FLOW & 0.04 & 0.09 & -0.05 & 0.00 & & & \\
\hline & $\mathrm{TT}$ & -0.12 & $-0.81 * *$ & $-0.73^{* *}$ & -0.06 & 0.05 & & \\
\hline & $\Delta \mathrm{TT}$ & -0.28 & -0.37 & -0.05 & -0.29 & -0.45 & -0.06 & \\
\hline & SURV & 0.00 & 0.22 & 0.18 & 0.09 & 0.14 & -0.22 & -0.15 \\
\hline \multirow[t]{7}{*}{1997} & FLOW & 0.49 & & & & & & \\
\hline & $\mathrm{SP} \%$ & $0.56^{*}$ & $0.94 * *$ & & & & & \\
\hline & TEMP & $0.80 * *$ & 0.42 & 0.46 & & & & \\
\hline & $\Delta$ FLOW & -0.30 & -0.19 & -0.12 & -0.09 & & & \\
\hline & $\mathrm{TT}$ & $-0.79 * *$ & $-0.80 * *$ & $-0.79 * *$ & $-0.62 *$ & 0.41 & & \\
\hline & $\Delta \mathrm{TT}$ & -0.40 & -0.24 & -0.23 & $-0.54 *$ & 0.11 & 0.47 & \\
\hline & SURV & -0.28 & -0.04 & 0.01 & -0.28 & 0.48 & 0.32 & 0.42 \\
\hline \multirow[t]{7}{*}{1998} & FLOW & $0.91 * *$ & & & & & & \\
\hline & $\mathrm{SP} \%$ & $0.72^{* *}$ & $0.87 * *$ & & & & & \\
\hline & TEMP & $0.74 * *$ & $0.56^{*}$ & 0.22 & & & & \\
\hline & $\Delta$ FLOW & 0.02 & 0.21 & $0.50 *$ & -0.34 & & & \\
\hline & $\mathrm{TT}$ & $-0.90^{* *}$ & $-0.82 * *$ & $-0.52^{*}$ & $-0.75^{* *}$ & 0.20 & & \\
\hline & $\Delta \mathrm{TT}$ & $-0.65^{*}$ & $-0.53 *$ & -0.44 & -0.46 & -0.13 & $0.65^{*}$ & \\
\hline & SURV & 0.30 & 0.29 & -0.15 & 0.31 & -0.19 & -0.28 & -0.07 \\
\hline \multirow[t]{7}{*}{1999} & FLOW & $0.53^{*}$ & & & & & & \\
\hline & $\mathrm{SP} \%$ & $0.55^{*}$ & 0.36 & & & & & \\
\hline & TEMP & $0.92 * *$ & $0.69 *$ & $0.51 *$ & & & & \\
\hline & $\Delta$ FLOW & -0.42 & 0.08 & -0.09 & -0.24 & & & \\
\hline & $\mathrm{TT}$ & $-0.89 * *$ & $-0.52 *$ & -0.33 & $-0.86^{* *}$ & 0.43 & & \\
\hline & $\Delta \mathrm{TT}$ & $-0.82^{* *}$ & -0.29 & -0.29 & $-0.74^{* *}$ & $0.54 *$ & $0.88 * *$ & \\
\hline & SURV & 0.11 & -0.17 & 0.18 & -0.05 & 0.01 & -0.06 & -0.01 \\
\hline
\end{tabular}

from the model sequences for TTIME versus DATE $\left(r^{2}=0.744\right)$ and for TTIME versus FLOW $\left(r^{2}=\right.$ 0.617), but a parallel regression for TTIME versus FLOW had only a slightly lower $r^{2}(0.593)$. In 1996, TTIME appeared more dependent on FLOW than on DATE, but the reverse appeared true in 1998. Indeed, at the beginning of the 1998 migration season, TTIME steadily decreased through time (Figure 2), whereas FLOW, SP\%, and TEMP all remained nearly constant, resulting in a markedly nonlinear relationship between TTIME and FLOW (Figure 3). These results suggest that travel time is influenced by both river discharge and smoltification and that the relative influence of each may vary from season to season.

As a single predictor, $\triangle \mathrm{FLOW}$ was not strongly correlated with TTIME (Table 2). Splines from a generalized additive model predicting TTIME from year effects, FLOW, DATE, and $\triangle$ FLOW suggested a parametric regression with a linear form for FLOW, a second-order polynomial for DATE, and a third-order polynomial for $\triangle$ FLOW (Figure 4):

TTIME $=$ intercept -1.99 .FLOW 23.42.DATE $-20.09 \cdot \mathrm{DATE}^{2}+3.64 \cdot \Delta \mathrm{FLOW}-$ $1.15 \Delta \cdot \mathrm{FLOW}^{2}-5.82 \cdot \Delta \mathrm{FLOW}^{3}$

$($ intercepts $=18.09,18.06,19.52,19.21$, and 16.13 for 1995-1999, respectively). All terms in the model were significant except the 1996 year effect and the second-order term for $\triangle \mathrm{FLOW}$, and $r^{2}$ for the model was 0.872 . The polynomial form for DATE incorporates the earlier finding that the average degree of smoltification of fish passing Low- 

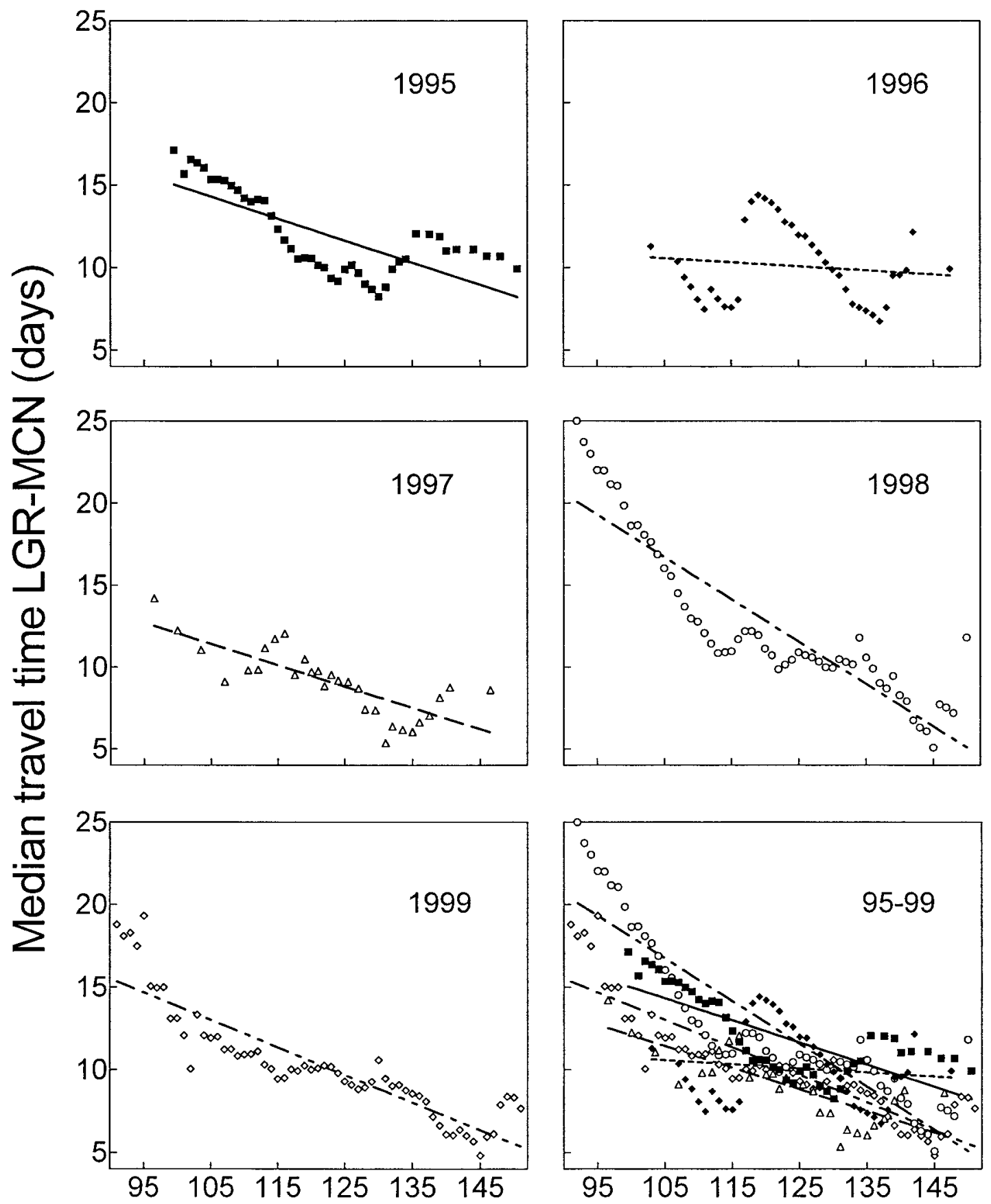

\section{Date at LGR (day of year)}

FIGURE 2.--Relation between median travel time from Lower Granite (LGR) Dam to McNary (MCN) Dam and release date from Lower Granite Dam for yearling chinook salmon, 1995-1999. Lines in the lower right panel depict the linear regression model identified in the model selection sequence. 

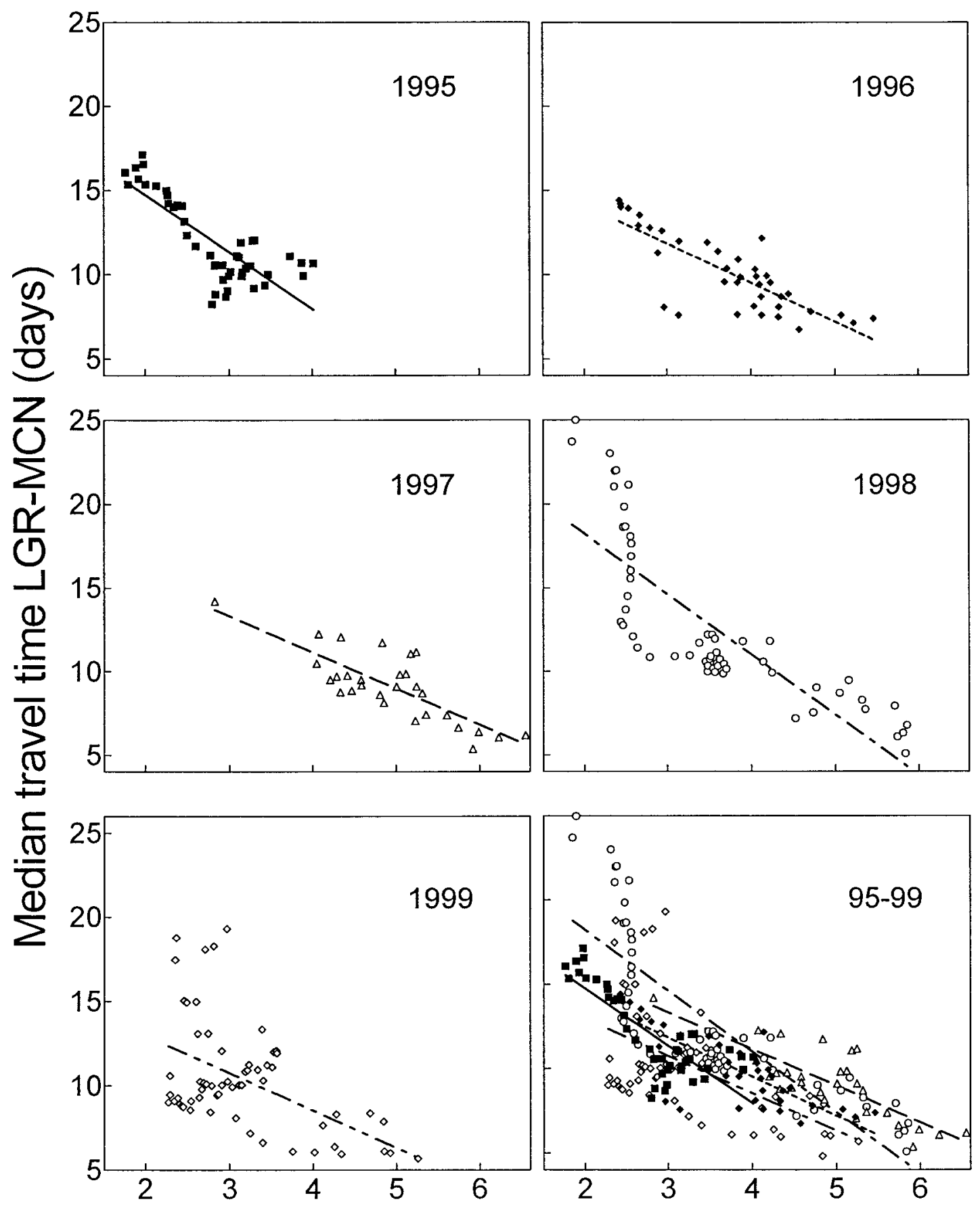

\section{Flow exposure index $\left(1000 \mathrm{~m}^{3} / \mathrm{s}\right)$}

FIGURE 3.- Relation between median travel time from Lower Granite (LGR) Dam to McNary (MCN) Dam and flow exposure index measured at Lower Monumental Dam for yearling chinook salmon, 1995-1999. Lines in the lower right panel depict the linear regression model identified in the model selection sequence. 


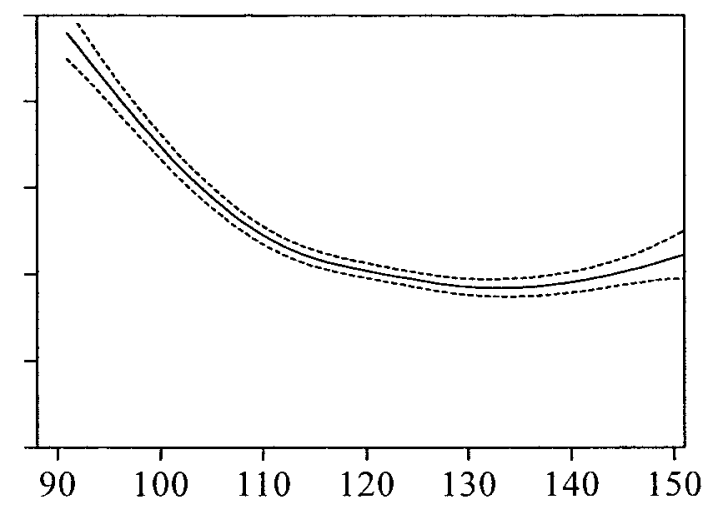

Date at LGR (day of year)

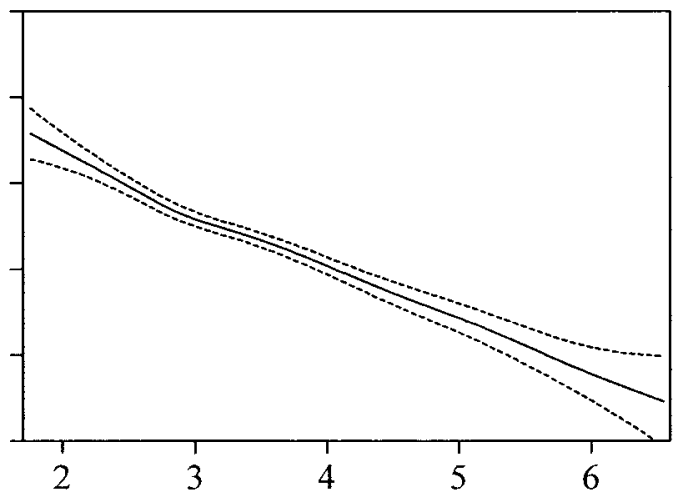

Flow exposure index $\left(1000 \mathrm{~m}^{3} / \mathrm{s}\right)$

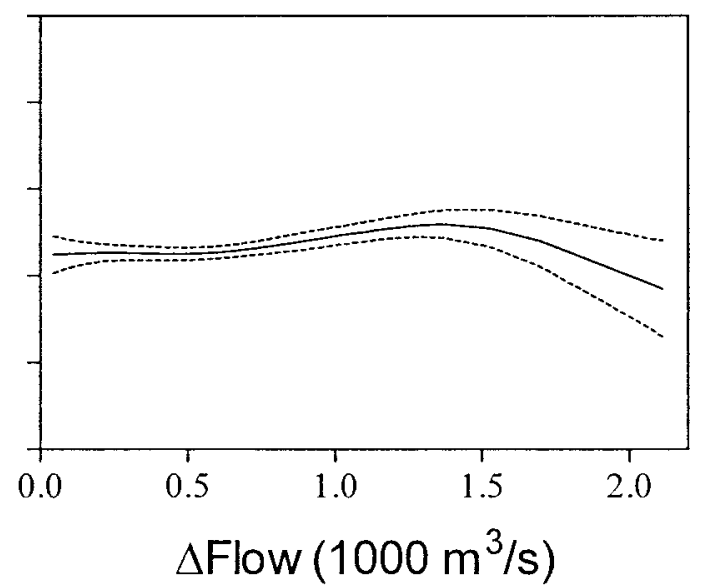

er Granite Dam may increase more rapidly early than it does later in the season (Figure 4). Only nine observations of $\triangle \mathrm{FLOW}$ were greater than 1.5 , so the estimated form of the TTIME/ $\Delta$ FLOW relation may be less reliable in that range (Figure 4). The form for the bulk of the data, which was less than 1.5, suggests that for a given average flow exposure for a group, travel times were shorter if the flow level was more consistent during the period in which the group was migrating (i.e., if the group spent less time migrating in low flow).

Variability in travel times $(\Delta \mathrm{TT})$ for individuals within a single group tended to decrease throughout the season as flow tended to increase and median travel time decreased (Table 2). However, $\Delta \mathrm{TT}$ was not correlated strongly or consistently with $\triangle$ FLOW, suggesting that variability in travel time depended chiefly on the total amount of time fish in a group were migrating through the index reach (i.e., longer overall travel times allow more time for fish from a single group to diffuse, resulting in more variability in travel times).

Estimated survival was not strongly or consistently related with any other variable (Table 2). Differences in annual mean survival accounted for $12.4 \%$ of the overall variability in estimated survival ( $r^{2}$ for year-effect model). The model selection sequence identified the parallel regressions model for the relation between SURV and DATE, suggesting a very slight increase in survival from beginning of the season to the end (Figure 5), but $r^{2}$ for this model increased only to 0.143 .

The correlation between SURV and FLOW was weak within each migration season, with a slight positive correlation within 3 years and a slight negative correlation within 2 (Figure 6). Only in 1998 was the weak (positive) correlation significant $\left(r^{2}=0.086 ; P=0.03\right)$. Combining years in the analysis, the relation between FLOW and SURV was nonsignificant $(P=0.39$ for parallel versus year effect). The year-effect model was selected. Results were similar for associations between SURV and TEMP and between SURV and $\triangle$ FLOW (Table 2).

Between SURV and TTIME, the correlation was

$\leftarrow$

FIGURE 4.-Partial fits for the generalized additive model of median travel time from Lower Granite (LGR) Dam to McNary Dam (d), with pointwise 95\% confidence intervals, for yearling chinook salmon, 19951999. The predictor variables were the release date from LGR Dam, the flow exposure index, the variability in flow ( $\Delta$ Flow), and year effects. 


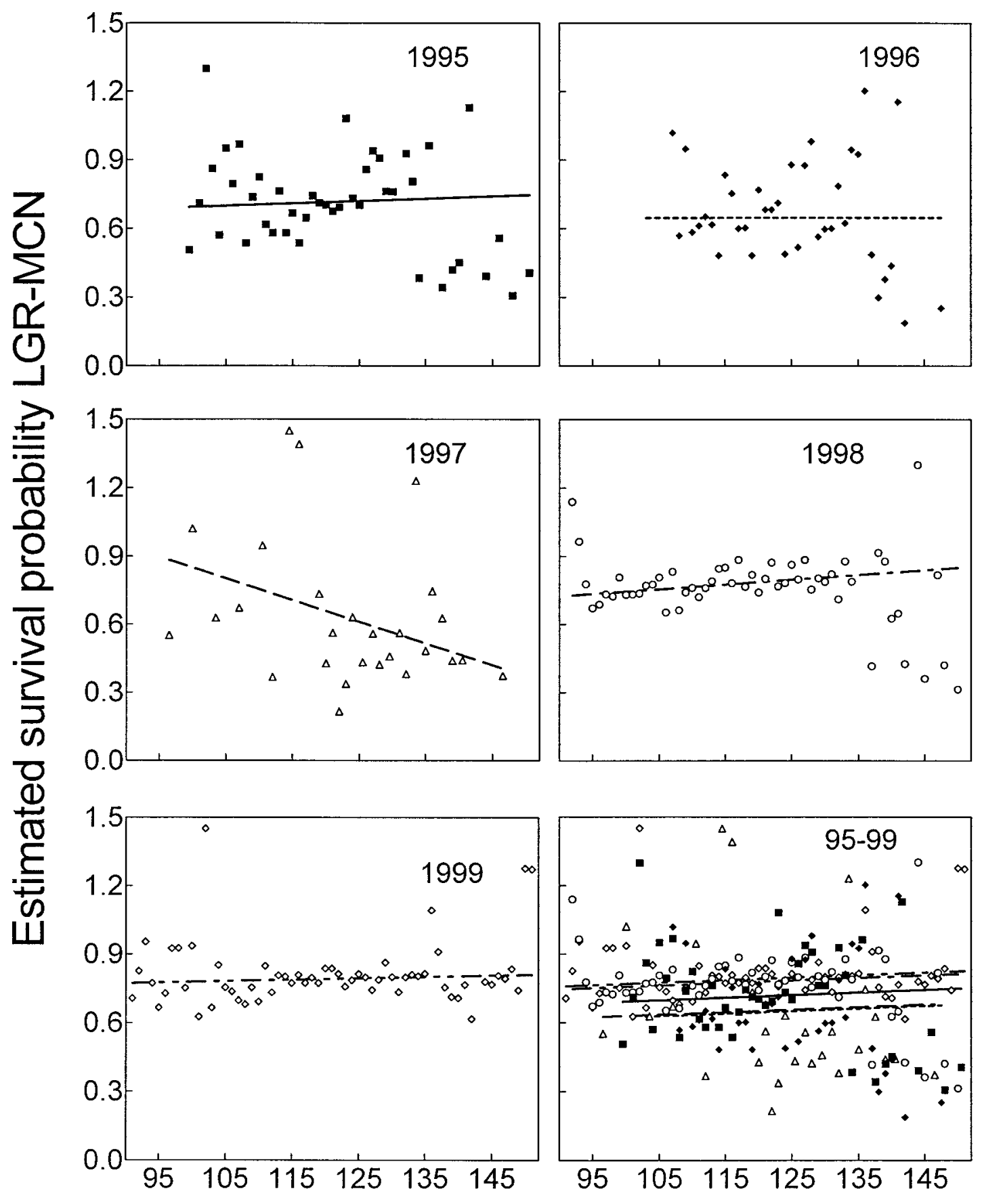

\section{Date at LGR (day of year)}

FIGURE 5.-Relation between estimated survival from Lower Granite (LGR) Dam to McNary (MCN) Dam and release date from Lower Granite Dam for yearling chinook salmon, 1995-1999. Lines in the lower right panel depict the linear regression model identified in the model selection sequence. Regression lines are from weighted analysis. 

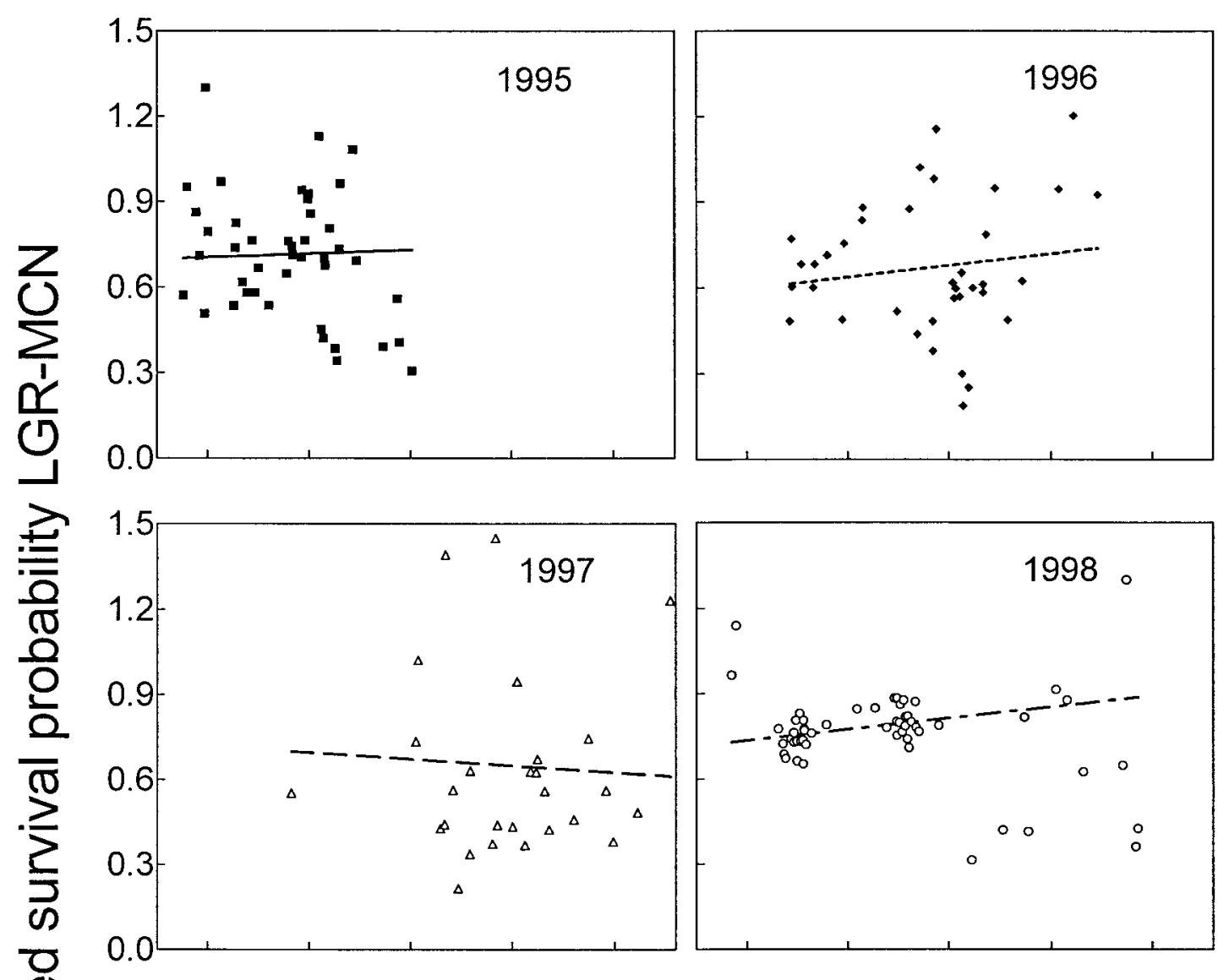

$\frac{0}{\frac{0}{\sigma}}$
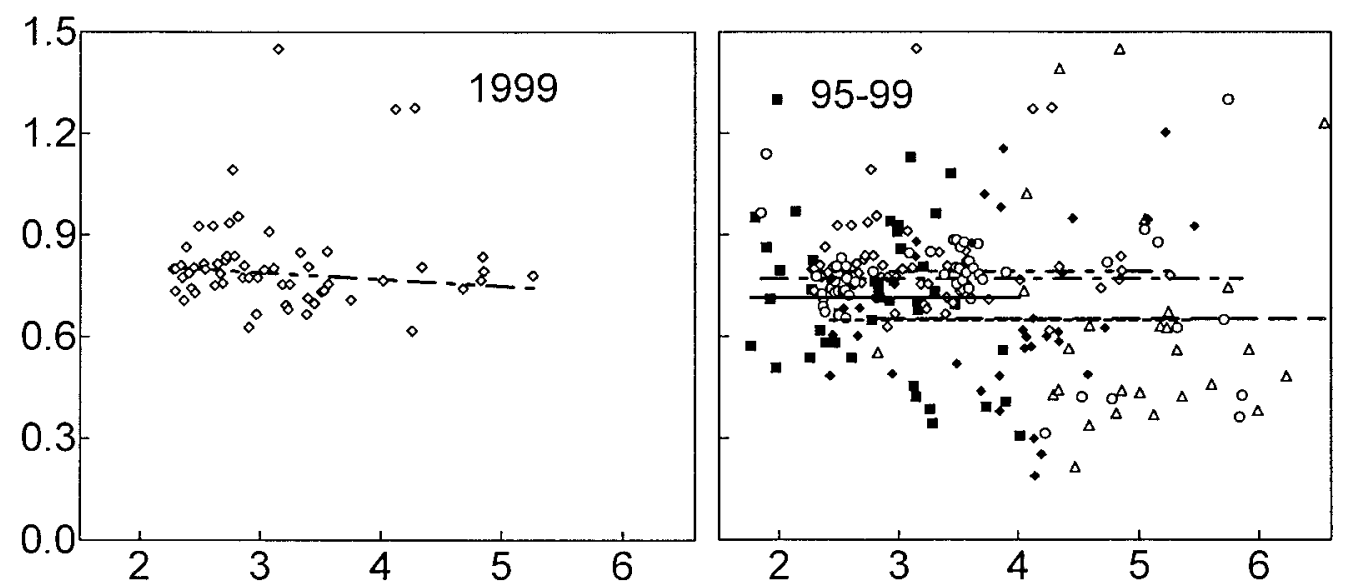

\section{Flow exposure index $\left(1000 \mathrm{~m}^{3} / \mathrm{s}\right)$}

FIGURE 6.- Relation between estimated survival from Lower Granite (LGR) Dam to McNary (MCN) Dam (d) and flow exposure index measured at Lower Monumental Dam for yearling chinook salmon, 1995-1999. Lines in the lower right panel depict the linear regression model identified in the model selection sequence. Regression lines are from weighted analysis. 
TABLE 3.-Product-moment correlation coefficients $(r)$ among dependent and independent variables for daily release groups of steelhead from Lower Granite Dam, 1995-1999. See the caption to Table 2 for additional information.

\begin{tabular}{|c|c|c|c|c|c|c|c|c|}
\hline \multirow[b]{2}{*}{ Year } & \multirow[b]{2}{*}{ Variable } & \multicolumn{7}{|c|}{ Variable } \\
\hline & & DATE & FLOW & $\mathrm{SP} \%$ & TEMP & $\Delta$ FLOW & $\mathrm{TT}$ & $\Delta \mathrm{TT}$ \\
\hline \multirow[t]{7}{*}{1995} & FLOW & $0.72 * *$ & & & & & & \\
\hline & SP\% & -0.01 & 0.43 & & & & & \\
\hline & TEMP & $0.85^{* *}$ & $0.64 *$ & -0.13 & & & & \\
\hline & $\Delta$ FLOW & -0.48 & -0.05 & 0.23 & -0.30 & & & \\
\hline & TT & $-0.75 * *$ & -0.40 & -0.21 & -0.44 & $0.63 *$ & & \\
\hline & $\Delta \mathrm{TT}$ & $-0.76 * *$ & -0.42 & 0.04 & $-0.58 *$ & 0.41 & $0.67 *$ & \\
\hline & SURV & 0.22 & 0.37 & 0.23 & 0.02 & -0.06 & -0.11 & -0.22 \\
\hline \multirow[t]{7}{*}{1996} & FLOW & 0.48 & & & & & & \\
\hline & SP\% & 0.42 & $0.81 * *$ & & & & & \\
\hline & TEMP & $0.78 * *$ & 0.37 & 0.34 & & & & \\
\hline & $\Delta$ FLOW & -0.13 & 0.00 & -0.14 & -0.28 & & & \\
\hline & TT & -0.48 & $-0.72 * *$ & $-0.86^{* *}$ & -0.36 & 0.28 & & \\
\hline & $\Delta \mathrm{TT}$ & $-0.58^{*}$ & -0.37 & -0.42 & -0.38 & -0.03 & 0.35 & \\
\hline & SURV & 0.05 & -0.07 & 0.11 & 0.04 & 0.00 & -0.24 & -0.14 \\
\hline \multirow[t]{7}{*}{1997} & FLOW & 0.08 & & & & & & \\
\hline & SP\% & 0.24 & $0.94 * *$ & & & & & \\
\hline & TEMP & $0.90 * *$ & 0.23 & 0.31 & & & & \\
\hline & $\Delta$ FLOW & -0.35 & 0.02 & 0.07 & -0.26 & & & \\
\hline & TT & $-0.71 * *$ & -0.29 & -0.37 & $-0.61 *$ & $0.53 *$ & & \\
\hline & $\Delta \mathrm{TT}$ & $-0.71 * *$ & -0.22 & -0.28 & $-0.65^{*}$ & 0.35 & $0.59 *$ & \\
\hline & SURV & 0.22 & 0.05 & 0.09 & 0.16 & 0.13 & 0.15 & -0.10 \\
\hline \multirow[t]{7}{*}{1998} & FLOW & $0.93 * *$ & & & & & & \\
\hline & $\mathrm{SP} \%$ & $0.72 * *$ & $0.84 * *$ & & & & & \\
\hline & TEMP & $0.72 * *$ & $0.63 *$ & 0.24 & & & & \\
\hline & $\Delta$ FLOW & -0.18 & -0.03 & 0.27 & -0.40 & & & \\
\hline & TT & $-0.89 * *$ & $-0.83 * *$ & $-0.57 *$ & $-0.72 * *$ & 0.24 & & \\
\hline & $\Delta \mathrm{TT}$ & $-0.66^{*}$ & $-0.63^{*}$ & -0.44 & -0.45 & 0.23 & $0.71 * *$ & \\
\hline & SURV & -0.15 & -0.04 & -0.12 & 0.21 & 0.04 & -0.02 & 0.15 \\
\hline \multirow[t]{7}{*}{1999} & FLOW & $0.66^{*}$ & & & & & & \\
\hline & $\mathrm{SP} \%$ & $0.53 *$ & 0.40 & & & & & \\
\hline & TEMP & $0.91 * *$ & $0.76 * *$ & 0.40 & & & & \\
\hline & $\Delta$ FLOW & 0.08 & 0.22 & -0.02 & 0.26 & & & \\
\hline & TT & $-0.75^{* *}$ & $-0.76 * *$ & -0.48 & $-0.69^{*}$ & -0.07 & & \\
\hline & $\Delta \mathrm{TT}$ & $-0.60 *$ & $-0.50 *$ & $-0.54 *$ & $-0.58 *$ & -0.38 & $0.58 *$ & \\
\hline & SURV & 0.01 & $0.51^{*}$ & 0.09 & 0.19 & 0.17 & -0.38 & -0.38 \\
\hline
\end{tabular}

positive and nearly significant $(P=0.09$; longer travel time, greater survival) in 1997 and significant $(P=0.04)$ and negative (longer travel time, lower survival) in 1998 (Table 2), although in both cases $r^{2}$ was so low as to have almost no predictive value. The model selection sequence identified the parallel regressions model; the negative slope for TTIME indicated slightly lower survival for groups that had longer median travel times.

For yearling chinook salmon, we found no multiple regression models for SURV that included year effects and more than one other significant predictor variable.

\section{Steelhead}

We analyzed 207 daily groups $(204,569$ fish) of PIT-tagged steelhead (Table 1). Results for steelhead were similar to those for yearling chinook salmon. Correlations among variables followed similar patterns (Table 3). Correlation and model selection results for TTIME and $\Delta \mathrm{TT}$ were similar (Figures 7, 8; Table 3). Differences in annual mean travel time accounted for $14.2 \%$ of the overall variability in median travel time $\left(r^{2}\right.$ for year-effect model). As with yearling chinook salmon, results suggested that travel time for steelhead depended both on the river discharge volume and on the physiological state of the migrating fish (fish passing Lower Granite Dam later in the season were presumably more smolted). The median travel time for steelhead suggested the same nonlinear pattern common for yearling chinook salmon migration years. Patterns for steelhead, evidenced by runs of positive and negative residuals (Figure 7), perhaps reflect changes through time in the composition of the population of fish by hatchery source.

Models that included year effects and multiple environmental variables identified the same set of predictors for steelhead travel time as for yearling chinook salmon: DATE, FLOW, and $\triangle$ FLOW. Gen- 

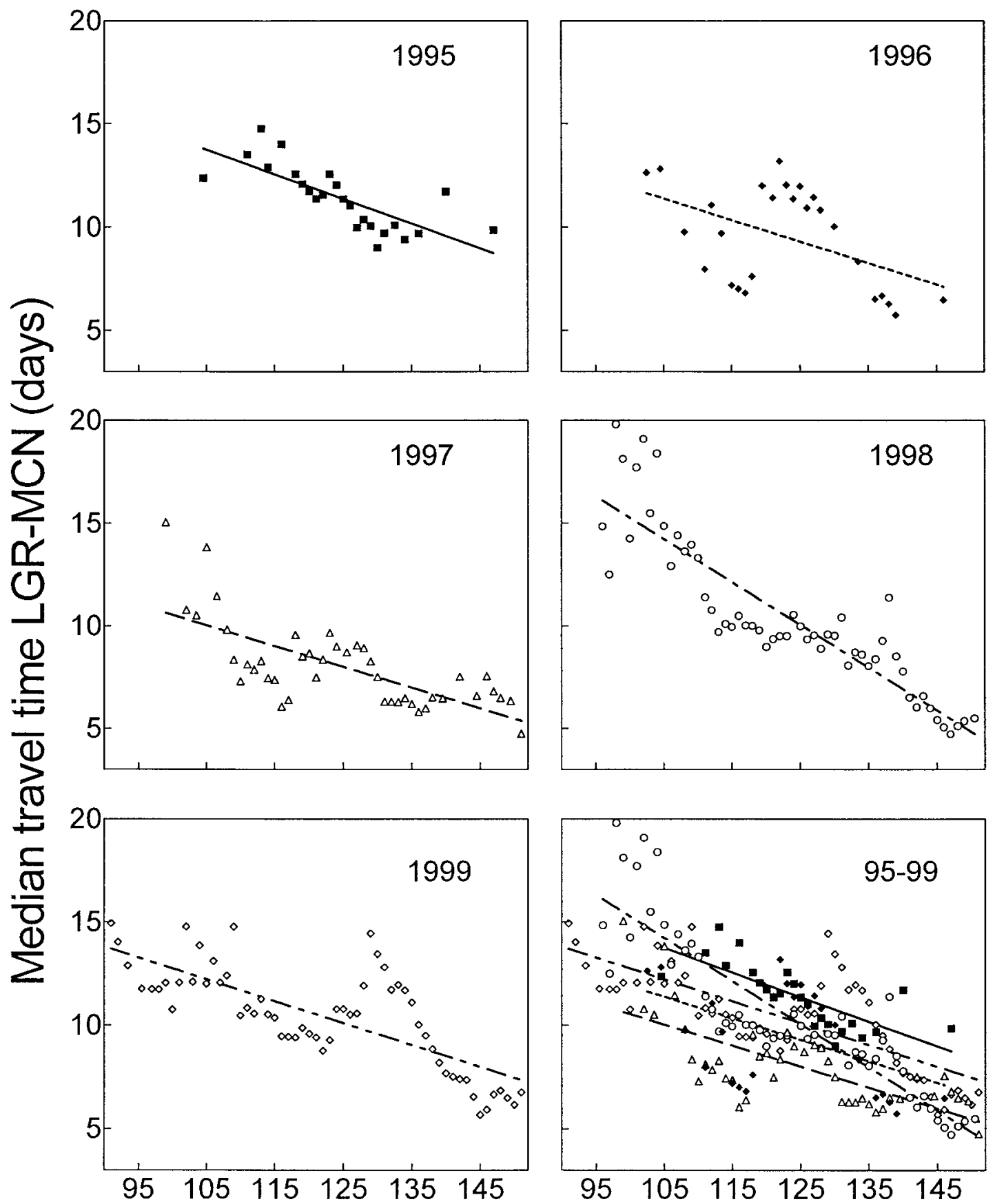

\section{Date at LGR (day of year)}

FIGURE 7.- Relation between median travel time from Lower Granite (LGR) Dam to McNary (MCN) Dam and release date from Lower Granite Dam for steelhead, 1995-1999. Lines in the lower right panel depict the linear regression model identified in the model selection sequence. 

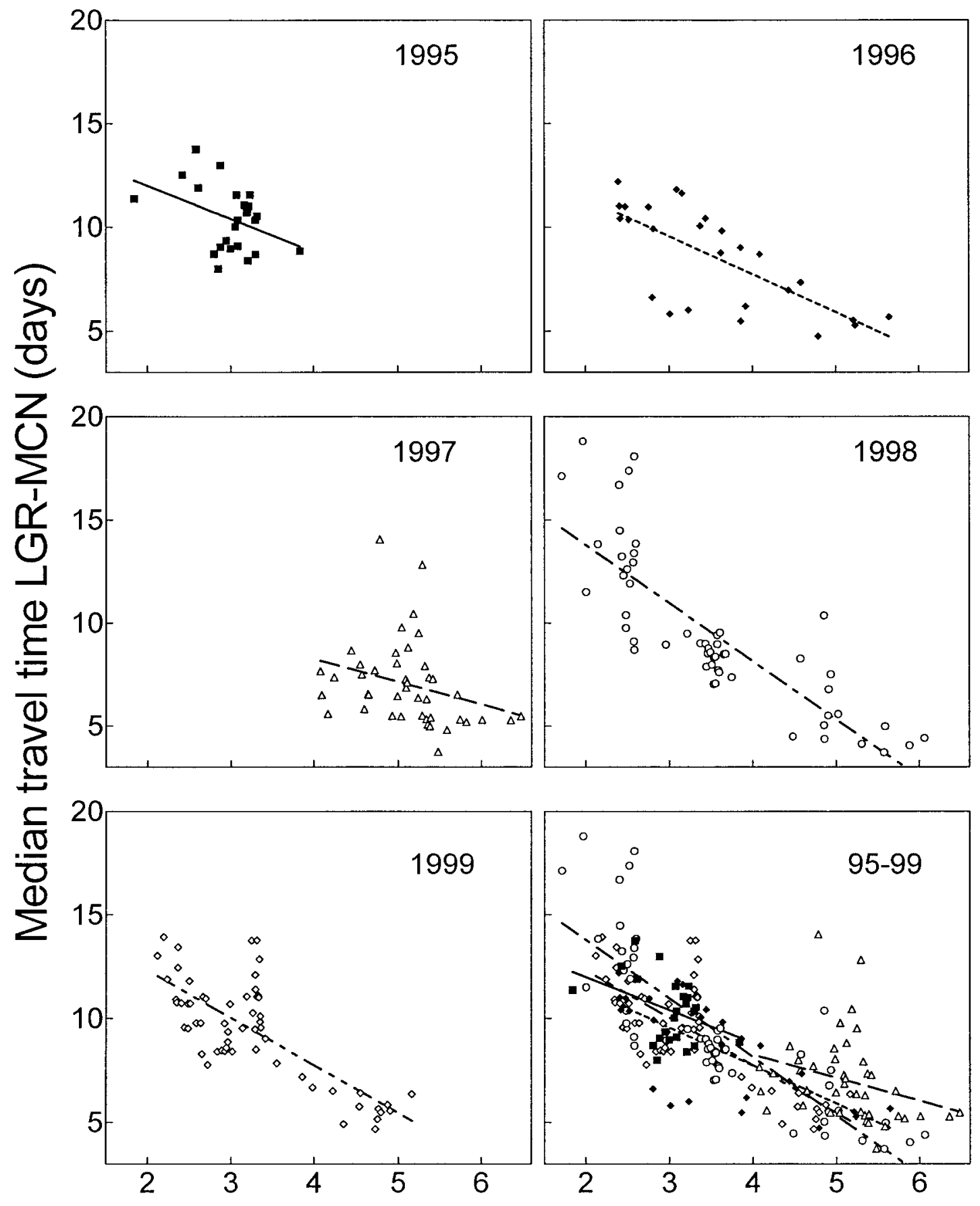

\section{Flow exposure index $\left(1000 \mathrm{~m}^{3} / \mathrm{s}\right)$}

FIGURE 8.-Relation between median travel time from Lower Granite (LGR) Dam to McNary (MCN) Dam and flow exposure index measured at Lower Monumental Dam for steelhead, 1995-1999. Lines in the lower right panel depict the linear regression model identified in the model selection sequence. 

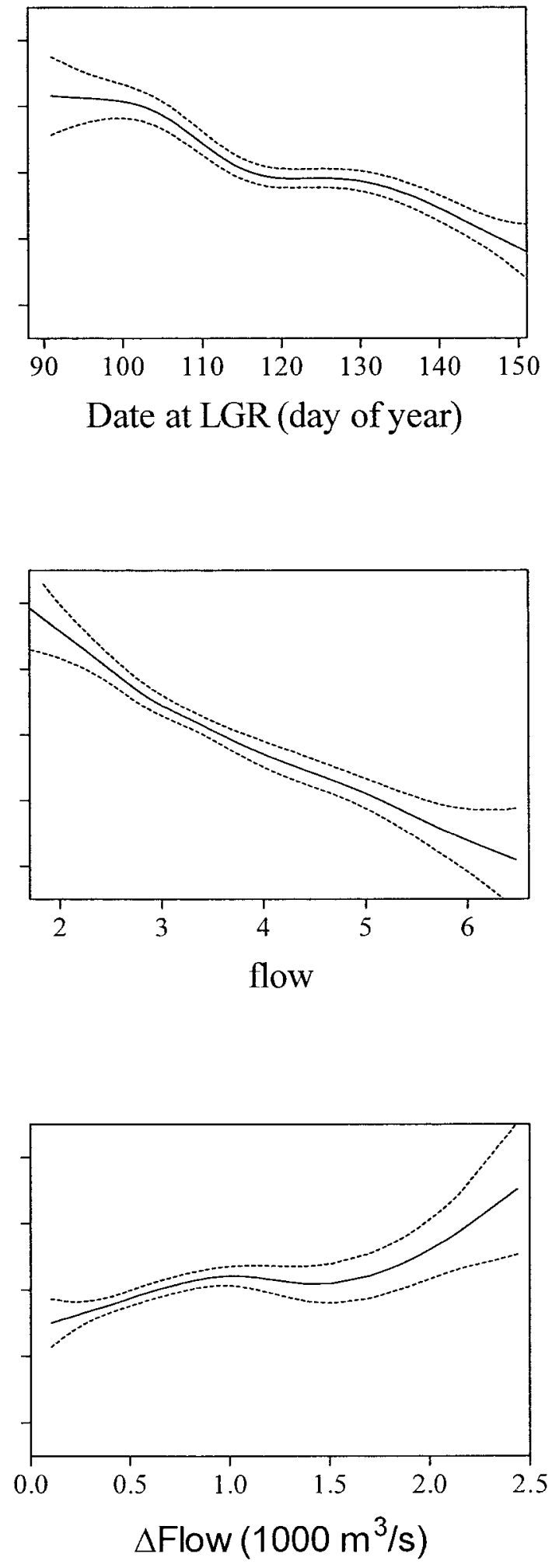

eralized additive model results indicated significant nonlinearity for all three variables (Figure 9). However, because incorporation of polynomial forms had minimal effect on fitted values and because the spline for each variable had a strong linear component (Figure 9), we selected the simpler multiple linear model for TTIME $\left(r^{2}=0.743\right)$ :

$$
\begin{aligned}
& \text { TTIME }=\text { intercept }-0.08 \cdot \text { DATE }- \\
& \text { 1.44.FLOW }+1.24 \cdot \Delta \text { FLOW }
\end{aligned}
$$

(intercepts $=23.94,22.19,23.30,23.62$, and 23.01 for 1995-1999, respectively).

Again as with yearling chinook salmon, correlations among survival estimates for steelhead and the dependent variables were generally weak and inconsistent from year to year (Table 3; Figures 10, 11).

Some results for steelhead survival that differed from those for yearling chinook salmon are worth noting. For steelhead, differences in annual mean survival were not significant; only $2.9 \%$ of overall variability was explained by differences in annual means ( $r^{2}$ for year-effect model). The model selection sequence identified the no-effect model for DATE and the parallel regressions model for FLOW. The latter model had a mild positive association between SURV and FLOW (survival increase of 0.040 for each additional $1,000 \mathrm{~m}^{3} / \mathrm{s}$; Figure 10), but $r^{2}$ was only 0.105 .

For steelhead, unlike for yearling chinook salmon, we found a multiple regression model for SURV that included year effects and more than one significant exposure variable. A generalized additive model did not indicate significant nonlinearity. The parametric multiple linear model equation was as follows:

$$
\begin{aligned}
& \text { SURV }=\text { intercept }-0.0047 \cdot \text { DATE }+ \\
& 0.0606 \cdot \text { FLOW }+0.0327 \cdot \text { TEMP }
\end{aligned}
$$

(intercepts $=0.778,0.711,0.644,0.605$, and 0.717 for 1995-1999, respectively; $\left.r^{2}=0.198\right)$.

\section{Discussion}

Our analyses provide additional evidence of a strong relation between flow and travel time (or

$\leftarrow$

FIGURE 9.-Partial fits for the generalized additive model of median travel time from Lower Granite (LGR) Dam to McNary Dam (d), with pointwise 95\% confidence intervals, for steelhead, 1995-1999. The predictor variables were the release date from LGR Dam, the flow exposure index $\left(1,000 \mathrm{~m}^{3} / \mathrm{s}\right)$, the variability in flow $(\Delta$ Flow), and year effects. 

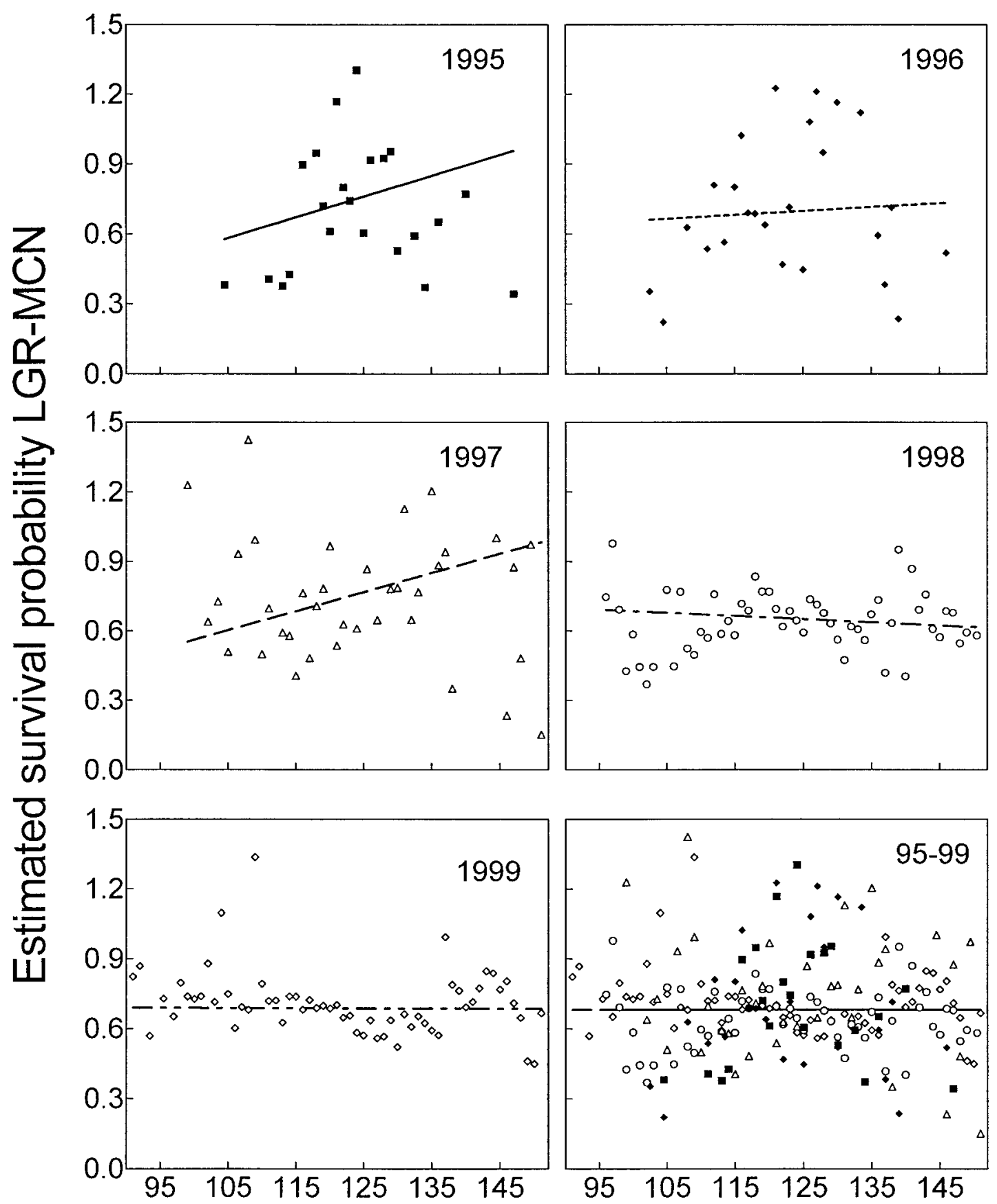

\section{Date at LGR (day of year)}

FIGURE 10.- Relation between estimated survival from Lower Granite (LGR) Dam to McNary (MCN) Dam and release date from LGR Dam for steelhead, 1995-1999. The line in the lower right panel depicts the linear regression model identified in the model selection sequence. Regression lines are from weighted analysis. 

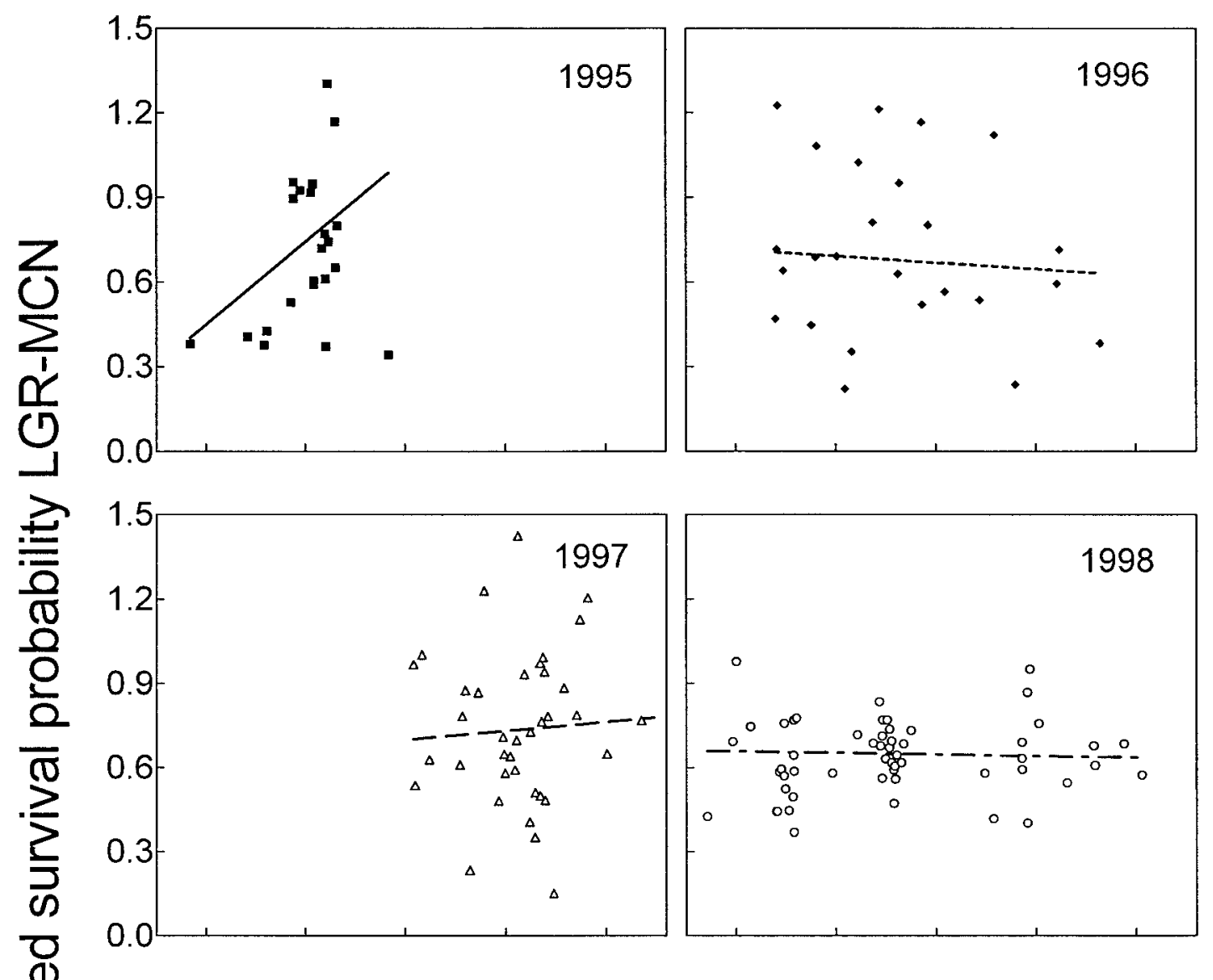

烍
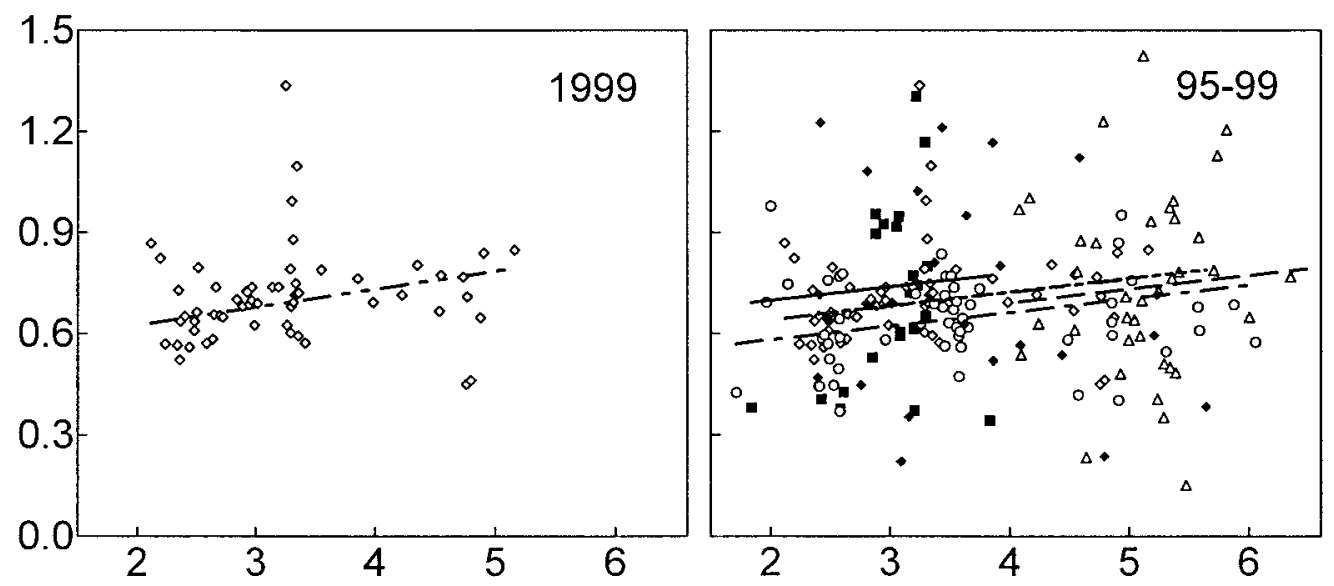

\section{Flow exposure index $\left(1000 \mathrm{~m}^{3} / \mathrm{s}\right)$}

FIGURE 11.- Relation between estimated survival from Lower Granite (LGR) Dam to McNary (MCN) Dam (d) and flow exposure index measured at Lower Monumental Dam for steelhead, 1995-1999. Lines in the lower right panel depict the linear regression model identified in the model selection sequence. Regression lines are from weighted analysis. 
migration rate) of migrant juvenile salmonids in the Snake River, as previously reported by other researchers (Raymond 1979; Berggren and Filardo 1993; Zabel et al. 1998). This relation was strong within single migration years and consistent from year to year. Our results also corroborate the hypothesis that travel time is influenced by the physiological development of the fish during smoltification (Berggren and Filardo 1993). In the upper Columbia River, in contrast, flow had little influence on travel times of yearling chinook salmon and only a moderate influence for steelhead (Berggren and Filardo 1993; Giorgi et al. 1997). Berggren and Filardo (1993) found that travel time for yearling chinook salmon in the mid-Columbia River was associated with release date, which they interpreted as a surrogate for smoltification.

Identifying and quantifying relations among environmental variables and travel times and the survival of release groups of PIT-tagged migrant juvenile salmonids in the Snake River present difficult challenges. Chief among these is that survival requires estimation for a group; however, individuals from a single group do not migrate together but instead spread out over time. If conditions change over a short time relative to the time it takes for the bulk of a release group to migrate through a particular river section, then different fish from the group will experience different environmental conditions. In this situation, estimated survival is usually representative of average survival for the group, but accurately summarizing the environmental conditions to which the entire release group was exposed and relating this summary to the survival estimates is indeed difficult. The same difficulty also affects travel time studies that use mass freeze branding (Berggren and Filardo 1993) because travel time for freeze-branded fish also requires estimation at the group level. The PIT tag affords the possibility of analyzing travel time for individual fish (Giorgi et al. 1997) - although we chose not to use this method; consequently, travel time analysis paralleled survival analysis. Even then, an individual fish experiences various levels of the same environmental factors over its juvenile migration of several weeks.

An advantage of PIT tagging over other marking methods is the ability to release multiple groups of tagged fish within a single migration season. However, if migration is protracted, the groups may have considerable overlap in downstream passage distributions, potentially further clouding the relation between survival and environmental variables by reducing contrast in the extents of ex- posures among the various groups. This also occurs when travel times for individual fish are analyzed.

Despite the aforementioned difficulties, we found highly significant correlations of median travel time with other variables. However, relations between flow and survival, and between travel time and survival through impounded sections of the lower Snake River, were neither strong (within or between years) nor consistent from year to year.

We were not able to study survival through the entire hydropower system because the rates of PIT tag detection in the lower Columbia River were too low to make reliable survival estimates in that part of the river. The $225-\mathrm{km}$ stretch over which survival was estimated for these analyses (Lower Granite Dam tailrace to McNary Dam tailrace) is $49 \%$ of the distance from Lower Granite Dam to Bonneville Dam. Relations between river discharge and survival of juvenile salmonids over the entire hydropower system remain unstudied.

Tailrace-to-tailrace survival is a function of the mortality that occurs both in the reservoirs and as fish pass the dams. Integrating across the three passage routes available at the lower Snake River dams (turbine, spillway, and bypass system) indicates total mortality for fish passing a dam probably ranges between 3\% and 5\% (Muir et al. 2001b). For single reaches, - that is, one reservoir and dam, tailrace to tailrace-survival estimates averaged $90 \%$ (Muir et al. 2001a), indicating that survival in reservoirs averaged between $93 \%$ and $95 \%$. Because physical passage conditions at dams are largely independent of discharge (although increased spill percentage might increase total passage survival by $1-2 \%$ ), variation in flow would probably more greatly affect reservoir mortality than dam-passage mortality. Thus, with the survival rates observed under the flow conditions that existed recently for spring-migrating smolts in the lower Snake River, it would seem that little room exists for increased flow to improve overall survival in that stretch of the river. Differences of this magnitude are difficult to detect. At some point, decreased flow lower than that we observed in recent years might result in decreased survival. Certainly we would expect travel time to increase.

We did not assess smolt development directly. However, using release date as a surrogate for smolt development, significant relations were found with travel time for both yearling chinook salmon and steelhead, similar to results of other studies (Berggren and Filardo 1993; Zabel et al. 
1998). In addition, results suggested that survival of chinook salmon increased significantly, though only slightly and with considerable unexplained variability, as the migration season progressed. For steelhead, release date was not a significant predictor of survival by itself, though the variable had a significant negative slope in multiple regression models. Interpretation of individual regression coefficients is complicated in multiple regression that includes collinearity of predictors. However, a negative relation between release date and survival for steelhead is consistent with the hypothesis that juvenile steelhead remaining in the river are more likely to revert to parr (residualize) as the season progresses.

To explore relations among travel time, survival, and environmental factors over the longest reach possible with available data (Lower Granite Dam to McNary Dam), we omitted survival estimates from 1993 and 1994 in the analysis presented here, because the PIT-tag interrogation system was not yet sufficiently developed. We could estimate survival over shorter reaches in those years (Muir et al. 2001a). During 1994, a spill program was implemented to improve the survival of yearling chinook salmon and steelhead, but not until late in the migration season after most fish had passed. Consequently, the years with the lowest per-project survival and lowest spill percentages (1993 and 1994) were excluded from our analysis. The 1994 migration was included in an earlier version of this analysis in which survival was estimated from Lower Granite Dam to Lower Monumental Dam (1993 was still excluded because survival estimates were available only to Little Goose Dam). The relation found between spill percentage and survival was significantly stronger than that for flow and survival in the combined-year analysis (Smith et al. 1998). Maximizing the survival and travel time distance in the present analysis (1995 through 1999) decreased the contrast in spill percentage and survival, which may account for the lack of a significant relation between the variables. In studies during the 1970s, Sims and Ossiander (1981) found that spill had a stronger correlation with survival than did flow. Passing a greater proportion of smolts through spill decreases the number of fish that pass through turbines, the route of dam passage with greatest direct mortality.

Previous attempts to quantify the relation between flow and survival (Raymond 1979; Sims and Ossiander 1981) related annual average survival to annual average flow. Significant relations were found, providing rationale for management programs based on flow augmentation by releasing water from storage reservoirs. Our multiple-year analyses are comparable to the earlier annual-average analyses. In the ranges of flow we observed in our studies of the Snake River hydropower system as it existed in the late 1990s, we found no consistent or significant correlation between yearling chinook salmon survival and flow, and only a weak relation for steelhead. Releases of PITtagged fish allowed us for the first time to move beyond annual averages to investigate relations within years. Results indicated that patterns previously suggested by analysis of annual means are not necessarily present within a single migration season; even for steelhead the correlation was negative (but not significant) for 2 of the 5 years.

This study confirmed a strong and consistent relation between flow and travel time and demonstrated the potential influence on travel time of a program designed to augment discharge volume with releases from upstream storage reservoirs. Although within-season flow-survival relations through the impounded sections of the Snake River that we investigated were weak at best, greater main-stem flow during smolt migration may provide survival benefits in other portions of the salmonid life cycle and in free-flowing sections of the river both upstream and downstream from the hydropower system. For example, greater flow might provide the greatest survival benefit to juvenile salmonids migrating through the estuary or the Columbia River plume, where they enter the ocean. Zabel and Williams (2002) found that date of arrival at Lower Granite Dam as a juvenile in 1995 correlated with rate of return as adults. Laterarriving fish had lower return rates, suggesting that travel time through the hydropower system may effect subsequent survival.

Yearling chinook salmon and steelhead have evolved to migrate during the spring, suggesting that over the evolutionary time scale, spring conditions, which include greater river flow, provide an adaptive advantage for survival. Furthermore, variable flow is a natural part of river ecology, benefiting other riverine processes (Stanford et al. 1996; Williams et al. 1996). The impoundment of the Snake and Columbia rivers has delayed the timing of ocean entry for migrating juvenile salmonids, and any management action that restores normative timing may be beneficial (Williams et al. 1996). Other researchers have suggested that adult salmon returns increased after high-flow years (Smoker 1955; Scarnecchia 1981; Petrosky 
and Schaller 1992). We will have complete adult return data from the juveniles evaluated in these studies by July 2002. At that time, we will examine adult return data to explore associations between environmental variables during smolt migration and smolt-to-adult survival.

\section{References}

Berggren, T. J., and M. J. Filardo. 1993. An analysis of variables influencing the migration of juvenile salmonids in the Columbia River basin. North American Journal of Fisheries Management 13:48-63.

Burnham, K. P., D. R. Anderson, G. C. White, C. Brownie, and K. H. Pollock. 1987. Design and analysis methods for fish survival experiments based on release-recapture. American Fisheries Society, Monograph 5, Bethesda, Maryland.

Cada, G. F., M. D. Deacon, S. V. Mitz, and M. S. Bevelhimer. 1995. Effects of water velocity on the survival of downstream-migrating juvenile salmon and steelhead: a review with emphasis on the Columbia River. Reviews in Fisheries Science 5:131183.

Cormack, R. M. 1964. Estimates of survival from the sightings of marked animals. Biometrika 51:429438.

Giorgi, A. E., T. W. Hillman, J. R. Stevenson, S. G. Hays, and C. M. Peven. 1997. Factors that influence the downstream migration rates of juvenile salmon and steelhead through the hydroelectric system in the mid-Columbia River basin. North American Journal of Fisheries Management 17:268-282.

Jolly, G. M. 1965. Explicit estimates from capture-recapture data with both death and immigration-stochastic model. Biometrika 52:225-247.

MathSoft. 2000. S-Plus 6.0 guide to statistics, volume 1. MathSoft, Seattle.

Muir, W. D., S. G. Smith, J. G. Williams, E. E. Hockersmith, and J. R. Skalski. 2001a. Survival estimates for migrant yearling chinook salmon and steelhead tagged with passive integrated transponders in the Lower Snake and Lower Columbia rivers, 1993-1998. North American Journal of Fisheries Management 21:269-282.

Muir, W. D., S. G. Smith, J. G. Williams, and B. P. Sandford. 2001b. Survival of juvenile salmonids passing through bypass systems, turbines, and spillways with and without flow deflectors at Snake River dams. North American Journal of Fisheries Management 21:135-146.

National Research Council. 1996. Upstream: salmon and society in the Pacific Northwest. National Academy Press, Washington, D.C.

Neter, J., W. Wasserman, and M. H. Kutner. 1985. Applied linear statistical models, 2nd edition. Richard D. Irwin, Inc., Homewood, Illinois.

Northwest Power Planning Council. 1994. 1994 Columbia River Basin fish and wildlife program. Northwest Power Planning Council, Document 94-55, Portland, Oregon.

Petrosky, C. E., and H. A. Schaller. 1992. A comparison of productivities for Snake River and lower Columbia River spring and summer chinook stocks. Pages 247-268 in Salmon management in the 21st century: recovering stocks in decline. American Fisheries Society Idaho Chapter, Idaho Water Resources Research Institute, and American Fisheries Society Western Division, Moscow, Idaho.

Prentice, E. F., T. A. Flagg, and C. S. McCutcheon. 1990a. Feasibility of using implantable passive integrated transponder (PIT) tags in salmonids. Pages 317-322 in N. C. Parker, A. E. Giorgi, R. C. Heidinger, D. B. Jester, Jr., E. D. Prince, and G. A. Winans, editors. Fish-marking techniques. American Fisheries Society, Symposium 7, Bethesda, Maryland.

Prentice, E. F., T. A. Flagg, C. S. McCutcheon, and D. F. Brastow. 1990b. PIT-tag monitoring systems for hydroelectric dams and fish hatcheries. Pages 323 334 in N. C. Parker, A. E. Giorgi, R. C. Heidinger, D. B. Jester, Jr., E. D. Prince, and G. A. Winans, editors. Fish-marking techniques. American Fisheries Society, Symposium 7, Bethesda, Maryland.

Prentice, E. F., T. A. Flagg, C. S. McCutcheon, D. F. Brastow, and D. C. Cross. 1990c. Equipment, methods, and an automated data-entry station for PIT tagging. Pages 335-340 in N. C. Parker, A. E. Giorgi, R. C. Heidinger, D. B. Jester, Jr., E. D. Prince, and G. A. Winans, editors. Fish-marking techniques. American Fisheries Society, Symposium 7, Bethesda, Maryland.

Raymond, H. L. 1979. Effects of dams and impoundments on migrations of juvenile chinook salmon and steelhead from the Snake River, 1966-1975. Transactions of the American Fisheries Society 108:505529.

Raymond, H. L. 1988. Effects of hydroelectric development and fisheries enhancement on spring and summer chinook salmon and steelhead in the Columbia River basin. North American Journal of Fisheries Management 8:1-24.

Scarnecchia, D. L. 1981. Effects of streamflow and upwelling on yield of wild coho salmon (Oncorhynchus kisutch) in Oregon. Canadian Journal of Fisheries and Aquatic Sciences 38:471-475.

Seber, G. A. F. 1965. A note on the multiple recapture census. Biometrika 52:249-259.

Sims, C., and F. Ossiander. 1981. Migrations of juvenile chinook salmon and steelhead in the Snake River, from 1973 to 1979 , a research summary. U.S. National Marine Fisheries Service, Northwest Fisheries Science Center Report to the U.S. Army Corps of Engineers, Contract DACW68-78-0038, Seattle.

Smith, S. G., W. D. Muir, E. E. Hockersmith, S. Achord, M. B. Eppard, T. E. Ruehle, and J. G. Williams. 1998. Survival estimates for the passage of juvenile salmonids through Snake River dams and reservoirs, 1996. U.S. National Marine Fisheries Service, Northwest Fisheries Science Center Report to Bonneville Power Administration, Project 93-29, Portland, Oregon.

Smoker, W. A. 1955. Effects of streamflow on silver 
salmon production in western Washington. Doctoral dissertation. University of Washington, Seattle.

Sokal, R. R., and F. J. Rohlf. 1981. Biometry, 2nd edition. Freeman, New York.

Stanford, J. A., J. V. Ward, W. J. Liss, C. A. Frissell, R. N. Williams, J. A. Lichatowich, and C. C. Coutant. 1996. A general protocol for restoration of regulated rivers. Regulated Rivers Research and Management 12:391-413.

Weisberg, S. 1985. Applied linear regression, 2nd edition. Wiley, New York.

Williams, R. N., L. D. Calvin, C. C. Coutant, M. W. Erho, Jr., J. A. Lichatowich, W. J. Liss, W. E. McConnaha, P. R. Mundy, J. A. Stanford, R. R. Whitney, D. L. Bottom, and C. A. Frissell. 1996.
Return to the river: restoration of salmonid fishes in the Columbia River ecosystem. Development of an alternative conceptual foundation and review and synthesis of science underlying the fish and wildlife program of the Northwest Power Planning Council. Northwest Power Planning Council, Report 96-6, Portland, Oregon.

Zabel, R. W., J. J. Anderson, and P. A. Shaw. 1998. A multiple-reach model describing the migratory behavior of Snake River yearling chinook salmon (Oncorhynchus tshawytscha). Canadian Journal of Fisheries and Aquatic Sciences 55:658-667.

Zabel, R. W., and J. G. Williams. 2002. Selective mortality for fish length and migrational timing in chinook salmon: what is the role of human disturbance? Ecological Applications 12:173-183. 